\title{
Detection of bacterial interaction with lactoferrin by an enzyme-linked ligand binding assay (ELBA)
}

\author{
A. R. KISHORE*, J. ERDEI, S. KALFAS*, A. FORSGREN and A. S. NAIDU \\ Department of Medical Microbiology, Malmö General Hospital, University of Lund, S-21401 Malmö, \\ and "Department of Oral Microbiology, Centre for Oral Health Sciences, S-214 21 Malmö, Sweden
}

\begin{abstract}
Summary. An enzyme-linked ligand binding assay (ELBA) was devised to measure the interaction between bacteria and human $(\mathrm{H})$ or bovine (B) lactoferrin (Lf) linked to horseradish peroxidase. Reagents were calibrated for optimum colour development with $o$ phenylenediamine as chromophore and organisms that were either positive or negative in a radioisotope-labelled ligand binding assay (RLBA) with ${ }^{125} \mathrm{I}-\mathrm{Lf}$. Good correlation of $\mathrm{Lf}$ binding $(r=0.89)$ was found between ELBA and RLBA with 169 randomly selected strains of Escherichia coli. A semi-quantitative scoring system for ELBA, corresponding to a similar system for RLBA, was established and shown to be valid for 517 strains from seven species of bacterial pathogens. ELBA was used to measure bacterial Lf binding-saturation and displacement kinetics and shown to be comparable with RLBA. ELBA may be a suitable method for examining the binding of $L f$ to bacteria without the need for radioactive isotopes.
\end{abstract}

\section{Introduction}

Lactoferrin (Lf) is a mammalian iron-binding glycoprotein produced by polymorphonuclear leucocytes (PMNL) and exocrine glands, that occurs at a high concentration in milk and at mucosal surfaces. ${ }^{1-3}$ Since Lf binds to specific receptors on various eukaryotic cells, ${ }^{4-10}$ it has been suggested that it is involved in many physiological processes including intestinal iron absorption, amplification of inflammatory responses, antigen processing and antibody production..$^{6,6,11-13}$ Lf also binds to various microbial pathogens, ${ }^{14-25}$ and this interaction seems to potentiate its antimicrobial action. ${ }^{26-29}$ However, certain micro-organisms seem to utilise this interaction to acquire Lf-bound iron for growth. ${ }^{23,30,31}$

Studies on the interaction of Lf with eukaryotic or prokaryotic cells are generally performed with radioisotope-labelled ligand binding assays (RLBA) that require expensive equipment and strict radiation protection. Furthermore, isotope-labelled proteins are less stable because of continuous radioactivity-induced disintegration. Enzyme-linked Lf reagents have been used in Western blotting techniques to demonstrate specific Lf-binding proteins of bacteria. ${ }^{16,20,21}$ These reagents are easy to handle and are stable over a long period of storage. Therefore, an enzyme-linked ligand binding assay (ELBA) has been developed to measure the interaction of $L f$ with bacteria. This paper describes the standardisation of ELBA against an ${ }^{125}$ I-labelled

Received 9 Dec. 1991; accepted 10 Feb. 1992.

Correspondence should be sent to Dr A. S. Naidu.
Lf binding assay as a reference method, and the use of ELBA to measure saturation and binding-inhibition kinetics and the characterisation of the magnitude of Lf binding to various bacterial pathogens.

\section{Materials and methods}

\section{Lactoferrins and horseradish peroxidase}

Highly purified human Lf (HLf) from human milk, and bovine Lf (BLf) from bovine colostrum were obtained from US Biochemicals, Cleveland, OH, USA. Both Lf preparations were homogeneous when tested in ion-exchange (Mono- $Q$ column, Pharmacia AB, Uppsala, Sweden) and in molecular-sieve (TSK G4000 SW, LKB Produkter AB, Bromma, Sweden) highperformance liquid chromatography. Horseradish peroxidase (HRPO) was purchased from Sigma.

\section{Coupling of Lf to HRPO}

HRPO was coupled to HLf and BLf by a periodate method. ${ }^{32}$ Briefly, $0.2 \mathrm{ml}$ of $0.1 \mathrm{M}$ sodium-m-periodate was mixed with HRPO $0.4 \%$ (final volume, $1 \mathrm{ml}$ ) with constant stirring for $20 \mathrm{~min}$ at room temperature. Excess periodate was removed by overnight dialysis at $4^{\circ} \mathrm{C}$ against $1 \mathrm{mM}$ sodium acetate buffer, $\mathrm{pH} 4 \cdot 4$. After the addition of $20 \mu \mathrm{l}$ of $0.2 \mathrm{M}$ sodium carbonatebicarbonate buffer, $\mathrm{pH} 9.5$, the dialysate was mixed with $1 \mathrm{ml}$ of HLf or BLf $0.8 \%$ (dissolved in $0.01 \mathrm{M}$ sodium carbonate buffer, $\mathrm{pH} 9.5$ ) and incubated for $2 \mathrm{~h}$ at room temperature with constant stirring. A 0.1$\mathrm{ml}$ volume of fresh sodium borohydrate $0.4 \%$ was added and kept for a further $2 \mathrm{~h}$ at $4^{\circ} \mathrm{C}$. Finally, 
ovalbumin (Sigma) $2 \%$ in $0.1 \mathrm{ml}$ of phosphatebuffered saline (PBS), pH 7.2, was added to stabilise the HRPO-Lf conjugate. This procedure yielded HRPO-Lf conjugates with high binding activity. After dialysis against $\mathrm{PBS}$ at $4^{\circ} \mathrm{C}$ overnight the conjugate preparation was mixed with an equal volume of glycerol $50 \% \mathrm{v} / \mathrm{v}$ and stored at $-20^{\circ} \mathrm{C}$.

\section{Preparation of bacterial suspensions}

Escherichia coli strains, previously characterised for interaction with $\mathrm{Lf},{ }^{22}$ were used for the standardisation of ELBA. Bacteria were grown on colonisation factor antigen (CFA) agar and fresh overnight cultures were subcultured on CFA agar for $24 \mathrm{~h}$ at $37^{\circ} \mathrm{C}$. Bacterial growth was gently scraped with a sterile loop (Sarstedt, Numbrecht, Germany), mixed in PBS and thoroughly suspended with a vortex mixer (Vortex Genie 2, Scientific Industries, NY, USA). The suspension was centrifuged at $5300 \mathrm{~g}$ for $10 \mathrm{~min}$ and the bacteria were recovered as a pellet. The pellet was resuspended and washed twice in PBS. Finally, the bacterial density in PBS was optically adjusted to $10^{10}$ cells/ml (OD 0.125 at $600 \mathrm{~nm}$; Varian DMS 100S) for binding studies. The cell density of selected samples was confirmed by counting stained bacteria in a Petroff-Hausser chamber.

\section{Standardisation of $L f-E L B A$}

A suspension of $10^{9}$ bacteria in $0.1 \mathrm{ml}$ of PBS was mixed with $0.1 \mathrm{ml}$ of HRPO-Lf conjugate. After incubation at $37^{\circ} \mathrm{C}$ for $1 \mathrm{~h}$, the mixture was washed three times by centrifugation at $5300 \mathrm{~g}$ for $10 \mathrm{~min}$ with ice-cold PBS containing Tween-20 0.05\%. The supernate was aspirated carefully and the bacterial pellet was mixed with $0.5 \mathrm{ml}$ of $o$-phenylenediamine substrate $(30 \mathrm{mg}$ in $75 \mathrm{ml}$ of $0.1 \mathrm{M}$ sodium acetate buffer, pH 5.0, containing $40 \mu \mathrm{l}$ of $\mathrm{H}_{2} \mathrm{O}_{2}$, Sigma, $30 \%$ ) and incubated for $10 \mathrm{~min}$ at room temperature. The reaction was terminated with $0.25 \mathrm{ml}$ of $4 \mathrm{M} \mathrm{H}_{2} \mathrm{SO}_{4}$. A bacteria-free supernate from the reaction mixture was collected by centrifugation at $5300 \mathrm{~g}$ for $5 \mathrm{~min}$ and the absorbance was measured at $492 \mathrm{~nm}$, in a Reader Microelisa system (Organon Technika NV, Turnhout, Belgium).

\section{Standardisation of $L f-R L B A$}

HLf and BLf were labelled with $\mathrm{Na}^{125} \mathrm{I}$ (specific activity $629 \mathrm{GBq} / \mathrm{mg}$; DuPont Scandinavia AB, Stockholm, Sweden) with Iodobeads ${ }^{\star}$ (Pierce Chemicals Co., Rockford, IL, USA). ${ }^{33}$ The ${ }^{125}$ I-labelled Lf binding assay was used as a reference during standardisation of the ELBA, and done as described previously. ${ }^{18,19}$ Briefly, $10^{9}$ bacteria in $0.1 \mathrm{ml}$ of PBS were mixed with $0.1 \mathrm{ml}$ of PBS containing $c .8 \mathrm{ng}$ of ${ }^{125} \mathrm{I}-\mathrm{Lf}$ (specific activity $0.16 \mathrm{MBq} / \mu \mathrm{g}$ ) and incubated at $37^{\circ} \mathrm{C}$ for $1 \mathrm{~h}$. The binding reaction was terminated with $2 \mathrm{ml}$ of ice-cold PBS containing Tween-20 0.1\%,
Table I. Lf binding to an isogenic pair of $E$. coli strains by ELBA and RLBA

\begin{tabular}{lccc}
\hline \multicolumn{1}{c}{ Strain } & Lf-type & $\begin{array}{c}\text { ELBA } \\
\text { Absorbance } \\
\text { (SD) }\end{array}$ & $\begin{array}{c}\text { RLBA } \\
\text { Percentage } \\
\text { 125I-Lf binding (SD) }\end{array}$ \\
\hline E. coli $\mathrm{H} 10407$ & HLf & $0.20(0.03)$ & $9(2)$ \\
& BLf & $0.19(0.03)$ & $7(2)$ \\
E. coli $\mathrm{H} 10407(\mathrm{Lf})$ & HLf & $1.98(0.20)$ & $53(5)$ \\
& BLf & $1.96(0.21)$ & $41(4)$ \\
\hline
\end{tabular}

and after centrifugation at $5300 \mathrm{~g}$ for $15 \mathrm{~min}$, the supernate was aspirated. Radioactivity bound to the bacterial pellet was measured in a gamma counter (LKB Wallac Clinigamma 1272, Turku, Finland). Background radioactivity (from incubation mixtures without bacteria) was deducted, and the binding was expressed as a percentage calculated from the total labelled ligand added to the bacteria.

\section{Comparison of ELBA and RLBA}

The ELBA reagents were calibrated for optimal colour reactions with $E$. coli strains $\mathrm{H} 10407$ and $\mathrm{H} 10407$ (Lf) that served as negative and positive controls respectively in Lf-RLBA. The strains were tested 10 times in both ELBA and RLBA, each time with fresh cultures. The binding results were comparable and reproducible in both assays (table I). ELBA was further evaluated for a correlation between absorbance values and ${ }^{125} \mathrm{I}-\mathrm{Lf}$ percentage binding. For this purpose, 169 randomly selected strains of $E$. coli were examined. Parameters such as bacterial growth conditions, cell density and incubation conditions for binding were similar for both the assays. $E$. coli strain H10407 and variant H10407(Lf) were always included as negative and positive controls respectively.

\section{Saturation kinetics and displacement of bound $L f$}

ELBA was used to determine the saturation kinetics of the Lf-bacteria interaction as a function of time. HRPO-labelled HLf or BLf was incubated with cells of strain $\mathrm{H} 10407(\mathrm{Lf})$ for different periods, and the colour reactions were measured.

To determine the displaceability of the ligandbacteria interaction with the same strain, increasing amounts of unlabelled ligand (in homologous and heterologous combinations) were added to the reaction mixture containing HRPO-labelled HLf or BLf and incubated for $1 \mathrm{~h}$. The washing steps and the colour development were performed as described above.

\section{Screening of bacteria for $L$ f binding}

Clinical isolates of Staphylococcus aureus (43), Aeromonas hydrophila (40), E. coli (295), Prevotella intermedia (11), Shigella flexneri (35), Salmonella 


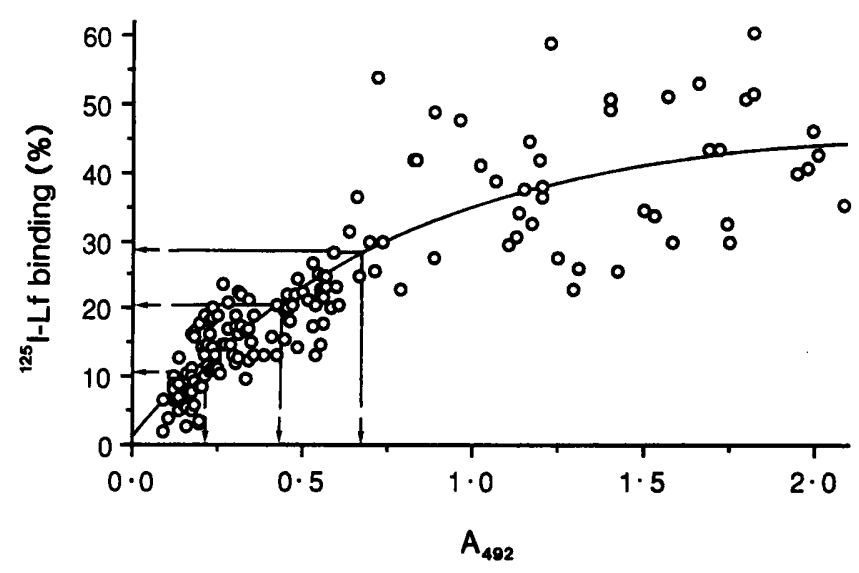

Fig. 1. Comparison of binding of HLf to 169 strains of E. coli by ELBA (absorbance at $492 \mathrm{~nm}$ ) and RLBA (percentage ${ }^{125}$ I-Lf binding).

Table II. Classification of ELBA scores according to the RLBA categories

\begin{tabular}{|c|c|c|c|}
\hline \multicolumn{2}{|r|}{ ELBA } & \multicolumn{2}{|r|}{ RLBA } \\
\hline Score & Absorbance interval & Category & $\begin{array}{c}\text { Percentage binding } \\
\text { interval }\end{array}$ \\
\hline $\begin{array}{l}0 \\
1 \\
2 \\
3\end{array}$ & $\begin{array}{c}\leqslant 0.22 \\
0.23-0.44 \\
0.45-0.66 \\
\geqslant 0.67\end{array}$ & $\begin{array}{l}\text { Negligible } \\
\text { Low } \\
\text { Moderate } \\
\text { High }\end{array}$ & $\begin{array}{c}\leqslant 10 \\
11-20 \\
21-30 \\
\geqslant 31\end{array}$ \\
\hline
\end{tabular}

typhimurium (37) and Yersinia enterocolitica (56) were examined. S. aureus strains isolated from patients with septicaemia, endocarditis or toxic shock syndrome were recovered and subcultured on Columbia agar. ${ }^{19}$ $P$. intermedia strains, from patients with periodontitis, were recovered and subcultured on modified Brucella blood agar. ${ }^{15}$ The enteropathogenic gram-negative bacteria isolated from the faeces of patients with gastroenteritis were recovered and subcultured on
CFA agar at $37^{\circ} \mathrm{C}$ for $24-72 \mathrm{~h}$, according to the requirement of each bacterial species. Cell suspensions were prepared and ELBA was performed according to the procedures described.

\section{Results}

To establish a correlation between ELBA and RLBA, 169 randomly selected $E$. coli strains were examined for HLf and BLf binding by each assay. The results expressed as percentage binding for RLBA and as absorbance at $492 \mathrm{~nm}$ for ELBA showed a third order polynomial correlation with a correlation coefficient of 0.89 (fig. 1). On the basis of these results an ELBA absorbance of 0.22 corresponding to $\leqslant 10 \%$ ${ }^{125}$ I-Lf binding was chosen as a class interval to define ELBA scores further to simplify the test (table II).

E. coli strains were redistributed according to ELBA scores and percentage ${ }^{125} \mathrm{I}-\mathrm{Lf}$ binding (fig. 2). The median values for HLf were $8 \%$ for score 0 and $16 \%$,
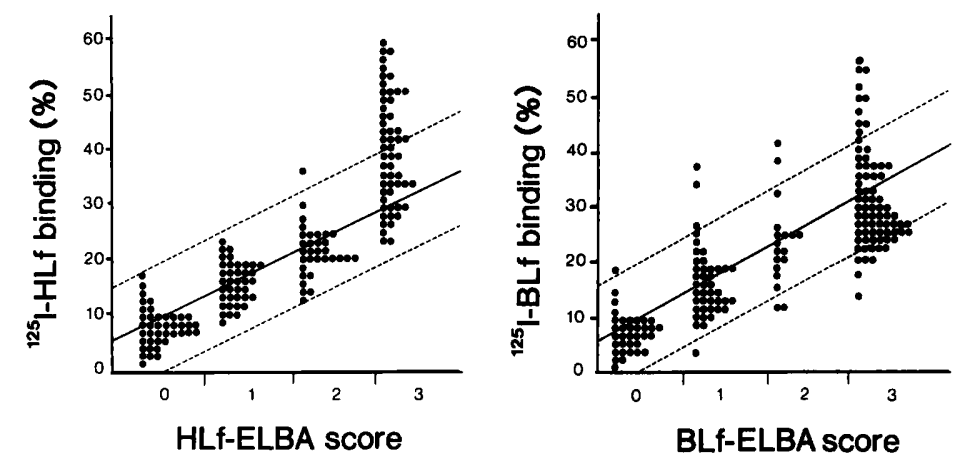

\begin{tabular}{|c|c|c|c|c|c|c|c|c|}
\hline \multirow{2}{*}{${ }^{125} \mathrm{I}$-LF binding } & \multicolumn{4}{|c|}{ HLf-ELBA score } & \multicolumn{4}{|c|}{ BLf-ELBA score } \\
\hline & 0 & 1 & 2 & 3 & 0 & 1 & 2 & 3 \\
\hline n & 41 & 42 & 32 & 54 & 35 & 42 & 18 & 75 \\
\hline Median & 8 & 16 & 22 & 39 & 7 & 17 & 23 & 29 \\
\hline Range & $2-19$ & $10-23$ & $13-37$ & $23-60$ & 2-19 & 3-38 & $12-42$ & $14-56$ \\
\hline Mean & 9 & 16 & 22 & 40 & 8 & 17 & 24 & 32 \\
\hline SD & 4 & 4 & 5 & 10 & 4 & 6 & 8 & 9 \\
\hline
\end{tabular}

Fig. 2. Comparision of percentage ${ }^{125} \mathrm{I}$-Lf binding and ELBA scores: _ _ interpolation of the mean values of score classes 0,1 and 2 ; , $-- \pm 10 \%$ RLBA binding range of the mean interpolation value. 
$22 \%$ and $39 \%$ for scores 1,2 and 3 respectively. Corresponding values for BLf were $7 \%, 17 \%, 23 \%$ and $29 \%$. In $c$. $75 \%$ of the strains (126 of 169$)$ the ELBA scores for the HLf coincided with the RLBA intervals. Eighteen strains were scored one class lower and 24 strains one class higher, but all deviations were within $\pm 10 \%$ of the RLBA binding interval. The corresponding values for BLf were $64 \%$ (108 of 169) for absolute matching; 12 strains were scored one class lower and 45 strains one class higher. Five strains deviated by two score classes (two strains lower and three strains higher). A value of $10 \%{ }^{125}$ I-labelled Lf binding had previously been considered to be the break-point for differentiating non-binding (= negligible binding) and binding strains. ${ }^{18,19}$ Based on this criterion, the sensitivity and specificity values for HLfELBA were estimated to be 0.92 and 0.94 , respectively. Corresponding values of 0.97 and 0.86 respectively, were obtained for BLf-ELBA.

The degree of HLf and BLf binding to 517 strains from seven bacterial species associated with various human infections were further examined with ELBA (table III). These ELBA score distributions corresponded well with RLBA results reported previously. ${ }^{15,16,19,22}$

The value of ELBA for the characterisation of the Lf-bacteria interaction was evaluated. The ELBA reaction with $E$. coli strain $\mathrm{H} 10407(\mathrm{Lf})$ was timedependent and $c .3 \mathrm{~h}$ was required for complete saturation with both $\mathrm{Lf}$ conjugates (fig. 3), and unlabelled HLf and BLf inhibited the binding of HRPO-HLf or HRPO-BLf to the strain in a dosedependent manner. About $150 \mu \mathrm{g}$ and $100 \mu \mathrm{g}$ of unlabelled ligand was required to give $50 \%$ inhibition (homologous or heterologous) of the HLf- and BLfELBA reactions respectively (fig. 4).

\section{Discussion}

ELBA may be considered to reflect Lf binding to approximately the same degree as RLBA. In addition, the four-class scoring system of ELBA will make it possible to develop a semi-quantitative test in which result will be read visually by comparing the colour
Table III. Percentage distribution of bacteria according to ELBA scores

\begin{tabular}{|c|c|c|c|c|c|c|c|c|}
\hline \multirow{2}{*}{$\begin{array}{l}\text { Bacterial species } \\
\text { (number of strains) }\end{array}$} & \multicolumn{8}{|c|}{$\begin{array}{l}\text { Percentage of strains that gave } \\
\text { ELBA scores for HLf ELBA scores for BLf }\end{array}$} \\
\hline & 0 & 1 & 2 & 3 & 0 & 1 & 2 & 3 \\
\hline S. aureus (43) & 63 & 30 & 2 & 5 & 5 & 21 & 37 & 37 \\
\hline A. hydrophila (40) & 0 & 10 & 22 & 68 & 0 & 8 & 27 & 65 \\
\hline E. coli $(295)$ & 39 & 41 & 5 & 15 & 40 & 42 & 6 & 12 \\
\hline P. intermedia (11) & 0 & 0 & 9 & 91 & 0 & 0 & 18 & 82 \\
\hline Sh. flexneri (35) & 23 & 46 & 3 & 28 & 0 & 43 & 26 & 31 \\
\hline Sal. typhimurium (37) & 16 & 49 & 5 & 30 & 5 & 35 & 21 & 39 \\
\hline Y. enterocolitica (56) & 20 & 18 & 44 & 18 & 12 & 9 & 9 & 70 \\
\hline
\end{tabular}

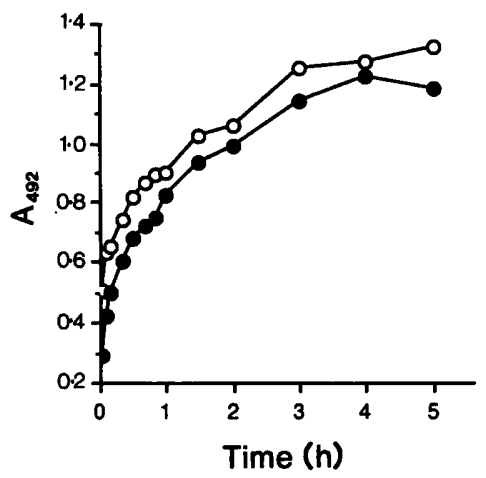

Fig. 3. Time-dependent binding of $\operatorname{HLf}(O)$ and $\operatorname{BLf}(O)$ to $E$. coli $\mathrm{H} 10407$ (Lf) as determined by ELBA.

intensity of the reaction against a colour chart, as previously described for other enzymatic reactions (API SYSTEM, La Balme les Grottes, France). Work is currently in progress to develop such a system.

Taken together, these results support the use of ELBA as an alternative to RLBA for measurement of the interaction of $L f$ with pathogenic micro-organisms. The standardised ELBA is reproducible and classifies the magnitude of $\mathrm{Lf}$ binding to bacteria with a sensitivity and specificity comparable to that of RLBA. ELBA may be particularly useful in laboratories that lack facilities for work with radioisotopes. Occasionally, interfering reactions that lead to increased background absorbance values with some bacteria may occur with the ELBA chromophore. Another possible limitation may be the large molecular size of the HRPO-Lf complex that may alter the binding to some
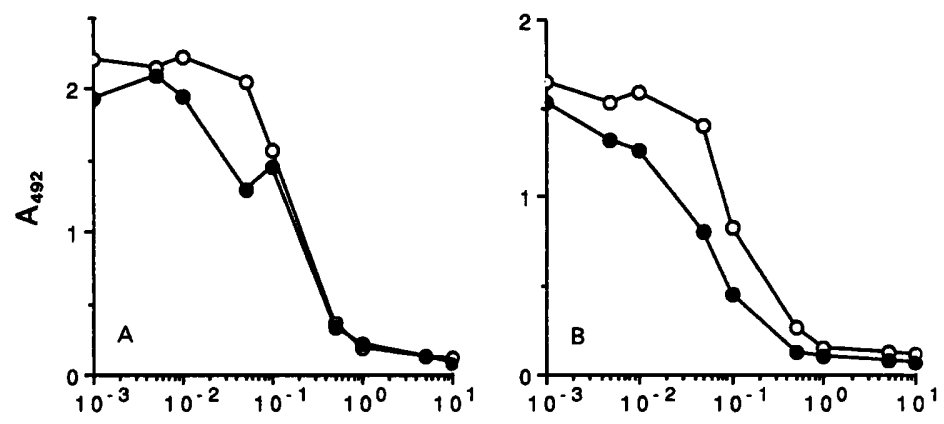

Concentration $(\mathrm{mg} / \mathrm{ml})$ of unlabelled $\mathrm{Lf}$

Fig. 4. Displacement of (a) HRPO-HLf and (b) HRPO-BLf binding from E. coli H10407(Lf) by unlabelled HLf (O) and BLf (O) as determined by ELBA. 
cells and thus affect estimations of the receptor density and binding affinity constants in Scatchard-plot analyses. Work is in progress to evaluate modifications of ELBA to suit these conditions.

\section{References}

1. Masson PL, Heremans JF, Dive CH. An iron-binding protein common to many external secretions. Clin Chim Acta 1966; 14: 735-739.

2. Masson PL, Heremans JF, Schonne E. Lactoferrin, an ironbinding protein in neutrophilic leukocytes. J Exp Med 1969 ; 130 : $643-658$.

3. Reiter B, Oram JD. Bacterial inhibitors in milk and other biological fluids. Nature $1967 ; 216$ : 328-330.

4. Bennett RM, Davis J. Lactoferrin binding to human peripheral blood cells: an interaction with a B-enriched population of lymphocytes and subpopulation of adherent mononuclear cells. J Immunol 1981; 127: 1211-1216.

5. Cox TM, Mazurier J, Spik G, Montreuil J, Peters TJ. Iron binding proteins and influx of iron across the duodenal brush border. Evidence for specific lactotransferrin receptors in the human intestine. Biochim Biophys Acta 1979; 588 : $120-128$.

6. Davidson LA, Lönnerdal B. Specific binding of lactoferrin to brush-border membrane: ontogeny and effect of glycan chain. Am J Physiol 1988; 254: G580-585.

7. Debanne MT, Regoeczi E, Sweeney GD, Krestynski F. Interaction of human lactoferrin with rat liver. Am J Physiol (Gastrointest Liver Physiol 11) 1985; 248: G463-G469.

8. Maneva AI, Sirakov LM, Manev VV. Lactoferrin binding to neutrophilic polymorphonuclear leucocytes. Int J Biochem 1983; 15: 981-984.

9. Rochard E, Legrand D, Mazurier J, Montreuil J, Spik G. The $\mathrm{N}$-terminal domain I of human lactotransferrin binds specifically to phytohemagglutinin-stimulated peripheral blood human lymphocyte receptors. FEBS Lett $1989 ; 255$ : 201-204.

10. van Snick JL, Masson PL. The binding of human lactoferrin to mouse peritoneal cells. $J$ Exp Med 1976; 144: 1568-1580.

11. Birgens HS. The biological significance of lactoferrin in haematology. Scand J Haematol 1984; 33: 225-230.

12. Broxmeyer HE, Smithyman A, Eger RR, Meyers PA, De Sousa $M$. Identification of lactoferrin as the granulocyte-derived inhibitor of colony-stimulating activity production. J Exp Med 1978; 148: 1052-1067.

13. van Snick JL, Masson PL, Heremans JF. The involvement of lactoferrin in the hyposideremia of acute inflammation. $J$ Exp Med 1974; 140: 1068-1084.

14. Alderete JF, Peterson KM, Baseman JB. Affinities of Treponema pallidum for human lactoferrin and transferrin. Genitourin Med 1988; 64: 359-363.

15. Kalfas S, Andersson M, Edwardsson S, Forsgren A, Naidu AS. Human lactoferrin binding to Porphyromonas gingivalis, Prevotella intermedia, and Prevotella melaninogenica. Oral Microbiol Immunol 1991 ; 6: 350-355.

16. Kishore AR, Erdei J, Naidu SS, Falsen E, Forsgren A, Naidu AS. Specific binding of lactoferrin to Aeromonas hydrophila. FEMS Microbiol Lett 1991; 83: 115-120.

17. Lee BC, Schryvers AB. Specificity of the lactoferrin and transferrin receptors in Neisseria gonorrhoeae. Mol Microbiol 1988; 2: 827-829.
This work was supported by SMR, the Swedish Dairies Association; Semper AB; STU, the Swedish Biotechnology Board; and the Alfred Österlunds Foundation. Dr J. Erdei is a visiting scientist from the Institute of Pathophysiology, University Medical School, Debrecen, Hungary.

18. Naidu AS, Miedzobrodzki J, Andersson M, Nilsson L-E, Forsgren A, Watts JL. Bovine lactoferrin binding to six species of coagulase-negative staphylococci isolated from bovine intramammary infections. J Clin Microbiol 1990; 28: 2312-2319.

19. Naidu AS, Miedzobrodzki J, Musser JM, Rosdahl VT, Hedström S-Å, Forsgren A. Human lactoferrin binding in clinical isolates of Staphylococcus aureus. J Med Microbiol 1991 ; 34: 323-328.

20. Naidu AS, Andersson M, Miedzobrodzki J, Forsgren A, Watts JL. Bovine lactoferrin receptors in Staphylococcus aureus isolated from bovine mastitis. J Dairy Sci 1991; 74 $1218-1226$.

21. Naidu AS, Andersson M, Forsgren A. Identification of a human lactoferrin-binding protein in Staphylecoccus aureus. J Med Microbiol 1992; 36: 177-183.

22. Naidu SS, Erdei J, Czirók É et al. Specific binding of lactoferrin to Escherichia coli isolated from human intestinal infections. APMIS 1991; 99: 1142-1150.

23. Peterson KM, Alderete JF. Iron uptake and increased intracellular enzyme activity follow host lactoferrin binding by Trichomonas vaginalis receptors. J Exp Med 1984; 160 . 398-410.

24. Schryvers AB, Morris LJ. Identification and characterization of the human lactoferrin-binding protein from Neisseria meningitidis. Infect Immun 1988; 56: 1144-1149.

25. Schryvers AB. Identification of the transferrin- and lactoferrinbinding proteins in Haemophilus influenzae. J Med Microbiol 1989; 29: 121-130.

26. Arnold RR, Cole MF, McGhee JR. A bactericidal effect for human lactoferrin. Science 1977; 197: 263-265.

27. Dalamastri C, Valenti P, Visca P, Vittorioso P, Orsi N. Enhanced antimicrobial activity of lactoferrin by binding to the bacterial surface. Microbiologica 1988; 11: 225-230.

28. Ellison RT, Giehl TJ, LaForce FM. Damage of the outer membrane of enteric gram-negative bacteria by lactoferrin and transferrin. Infect Immun 1988; 56: 2774-2781.

29. Lima MF, Kierszenbaum F. Lactoferrin effects on phagocytic cell function. I. Increased uptake and killing of an intracellular parasite by murine macrophages and human monocytes. $J$ Immunol $1985 ; 134$ : 4176-4183.

30. Brock JH, Pickering MG, McDowall MC, Deacon AG. Role of antibody and enterobactin in controlling growth of Escherichia coli in human milk and acquisition of lactoferrin- and transferrin-bound iron by Escherichia coli. Infect Immun 1983; 40: 453-459.

31. Mickelsen PA, Blackman, E, Sparling PF. Ability of Neisseria gonorrhoeae, Neisseria meningitidis, and commensal Neisseria species to obtain iron from lactoferrin. Infect Immun 1982; 35: 915-920.

32. Nakane PK, Kawaoi A. Peroxidase-labelled antibody. A new method of conjugation. J Histochem Cytochem 1974; 22 : 1084-1091.

33. Markwell MAK. A new solid-state reagent to iodinate proteins. 1. Conditions for the efficient labeling of antiserum. Anal Biochem 1982; 125: 427-432 